\title{
Comparative study on the biological characteristics of menstrual blood- and endometrium-derived endometrial cells
}

\author{
LEI ZHAO $^{1^{*}}$, MENG JI $^{2 *}$, ZHIFANG CHEN $^{1}$, LIN YUAN $^{1}$ and YAN DING ${ }^{1}$ \\ ${ }^{1}$ Gynecology Center of The First Affiliated Hospital of Xinjiang Medical University, Urumqi, \\ Xinjiang 830054; ${ }^{2}$ Hangzhou Biaomo Biosciences Co., Ltd., Hangzhou, Zhejiang 310018, P.R. China
}

Received June 19, 2020; Accepted August 5, 2021

DOI: $10.3892 / \mathrm{etm} .2021 .10856$

\begin{abstract}
During a woman's reproductive period, the endometrial tissue is shed and regenerated every month to prepare for pregnancy or for the next cycle. The aim of the present study was to isolate, culture and characterize human endometrial cells (ECs) derived from menstrual blood (MB) and the endometrium (E). MB-derived ECs (MB-ECs) were isolated from women's MB. E-derived ECs (E-ECs) were isolated from women's endometrial tissues. The present study investigated the epithelial cell marker cytokeratin 18 (CK18) in MB-ECs and E-ECs. Cell proliferation analyses indicated that E-ECs (population doubling time, $20.85 \mathrm{~h}$ ) grew faster than MB-ECs (population doubling time, $22.05 \mathrm{~h} ; \mathrm{P}<0.05$ ). Cell migration ability was found to be significantly greater for MB-ECs than for E-ECs at $48 \mathrm{~h}(\mathrm{P}<0.01)$. MB-ECs incubated with TGF- $\beta 1(3 \mathrm{ng} / \mathrm{ml})$ exhibited significantly decreased CK18 mRNA expression $(\mathrm{P}<0.01)$, and significantly increased vimentin $($ Vim $)$ mRNA $(\mathrm{P}<0.05)$ and protein $(\mathrm{P}<0.01)$ expression at 6 and $12 \mathrm{~h}$, respectively. E-EC incubation with TGF- $\beta 1$ (3 ng/ml) significantly decreased CK18 mRNA expression $(\mathrm{P}<0.01)$ at $12 \mathrm{~h}$ and significantly increased Vim mRNA $(\mathrm{P}<0.01)$ and protein expression $(\mathrm{P}<0.05)$ at $6 \mathrm{~h}$. The present results indicated that MB-ECs and E-ECs were biologically different, and that epithelial-mesenchymal transdifferentiation could be induced by TGF- $\beta 1$ treatment.
\end{abstract}

\section{Introduction}

The human endometrium (E) is a dynamic remodeling tissue, which in response to the prevailing steroid environment of

Correspondence to: Professor Yan Ding, Gynecology Center of The First Affiliated Hospital of Xinjiang Medical University, 1 Liyushan Road, Urumqi, Xinjiang 830054, P.R. China

E-mail: ddy8930@126.com

${ }^{*}$ Contributed equally

Key words: menstrual blood-derived endometrial cells, endometrium-derived endometrial cells, comparative study, biological characteristics, TGF- $\beta 1$-induced transdifferentiation sequential ovarian estrogen and progesterone exposure, undergoes $>400$ cycles of regeneration, differentiation and shedding during a woman's reproductive years $(1,2)$. Menstruation is the endometrial response to progesterone and estrogen withdrawal that occurs with the decay of the corpus luteum in the absence of pregnancy (1). Chan et al (3) first identified the endometrial epithelial and stromal cell clone formation ability, suggesting that there are three types of cells in the E: Epithelial, mesenchymal and endothelial cells. Smalley and Clarke (4) observed that endometrial epithelial cells had enhanced cloning activity during the proliferative phase, and stromal cells had stronger activity during the secretory phase.

Both epithelial and stromal cells are present in the basal layer of the human $\mathrm{E}$, and menstruation is formed after the top two-thirds of the functional layer of the E (2). Therefore, there may be some differences in biological characteristics between menstrual blood-derived endometrial cells (MB-ECs) and E-derived ECs (E-ECs). Ethical and practical considerations often limit the use of primary human E-ECs for research purposes (5). The acquisition of MB is not invasive and does not cause harm to the donor. MB-ECs isolated and cultured in vitro demonstrated high proliferation potential and the ability to differentiate into a variety of cells (6). Considering the easier access to MB, ECs have become a convenient source of adult cells and are a relevant cell source for the study of endometrial diseases $(7,8)$.

The present study compared MB-ECs and E-ECs to investigate the isolation, identification, culture, expansion and differentiation of ECs from two provenances, in order to identify entry points and lay a foundation for the treatment of gynecological diseases. The present study also provided important experimental and theoretical guidance to obtain different ECs by different means.

\section{Materials and methods}

Experimental materials. All samples were collected between March 2017 and April 2017 in under a protocol approved by the institutional review board of the Gynecology Center of The First Affiliated Hospital of Xinjiang Medical University (Urumqi, China), and written informed consent was obtained from each donor. Human endometrial tissue was obtained from patients (Table I) undergoing hysterectomy, and MB was obtained from healthy women. The age range of the patients 
and healthy controls was $26-43$ years. The inclusion criteria were as follows: Childbearing age (30-45 years), benign gynecological diseases, no fertility requirements, hysterectomy, no hormone treatment within 6 months, no or mild anemia, and no liver, kidney, heart, brain or blood system disorders. The exclusion criteria were as follows: Systemic or reproductive malignant disease, endometrial or intrauterine lesions, a history of hormone therapy within 3 months, endometriosis and adenomyosis. The patients were matched according to their age, menstrual history, fertility history, contraceptive methods, uterine size, lack of hormone treatment within 3 months and anemia. MB and endometrial tissues obtained from the resected uterus were used as the research objects.

Isolation and culture of MB-ECs and E-ECs. For MB-EC isolation, $5 \mathrm{ml}$ of $\mathrm{MB}$ samples from healthy women were collected, and $0.2 \mathrm{ml}$ amphotericin B (cat. no. 15290026), $0.2 \mathrm{ml}$ penicillin-streptomycin (cat. no. 15140122), $0.1 \mathrm{ml}$ $\mathrm{Na}_{2}$ EDTA (cat. no. 15576028) and $9.5 \mathrm{ml}$ PBS (cat. no. 20012050; all from Gibco; Thermo Fisher Scientific, Inc.) were added; this mixture was transferred to a laboratory at $4^{\circ} \mathrm{C}$. The cells were separated via centrifugation with $1.077 \mathrm{~g} / \mathrm{ml}$ Ficoll (cat. no. P8900; Beijing Solarbio Science \& Technology Co., Ltd.) at $500 \mathrm{x} \mathrm{g}$ for $30 \mathrm{~min}$ at room temperature, and the middle white membrane layer was collected. The separated cells were washed twice with PBS and cultured in a $60-\mathrm{mm}$ culture dish (cat. no. 430166; Corning Life Sciences) using complete DMEM/F12 (cat. no. 11320082; Gibco; Thermo Fisher Scientific, Inc.) + 10\% FBS (cat. no. FND500, Shanghai ExCell Biology, Inc.) $+1 \%$ penicillin-streptomycin, followed by incubation at $37^{\circ} \mathrm{C}$ with $5 \% \mathrm{CO}_{2}$. Cells were washed twice with PBS to remove non-adherent cells after 3 days.

For E-EC isolation, the surgically removed human endometrial tissues were washed in PBS to remove excess tissue and blood. The endometrial tissues were cut into $1-\mathrm{mm}^{3}$ pieces, then dissociated into single-cell suspensions using $200 \mu \mathrm{g} / \mathrm{ml}$ collagenase type IV (cat. no. C5138; Sigma-Aldrich; Merck KGaA) in DMEM/F12 with $10 \%$ FBS and mechanical methods for $1-2 \mathrm{~h}$ at $37^{\circ} \mathrm{C}$. The undigested endometrial tissues were incubated with $0.25 \%$ trypsin-EDTA (cat. no. 25200056 , Gibco; Thermo Fisher Scientific, Inc.) for $15 \mathrm{~min}$ at $37^{\circ} \mathrm{C}$. Single-cell suspensions were collected using a cell strainer, then centrifuged at $200 \mathrm{x} \mathrm{g}$ for $8 \mathrm{~min}$ at room temperature. The bottom cells were resuspended in complete medium, plated into a $60-\mathrm{mm}$ culture dish and incubated at $37^{\circ} \mathrm{C}$ in $5 \% \mathrm{CO}_{2}$. Cells were washed twice with PBS to remove non-adherent cells after $24 \mathrm{~h}$.

When cultures reached $90 \%$ confluence, cells were digested with warmed $0.25 \%$ trypsin-EDTA at $37^{\circ} \mathrm{C}$ for $3 \mathrm{~min}$, then subcultured onto fresh culture plates. To purify the cells, the isolated cells were screened using different time digestion methods. The cells were digested with warmed $0.25 \%$ trypsin-EDTA at $37^{\circ} \mathrm{C}$ for $1-2 \mathrm{~min}$, then digestion was stopped and the digested cells were removed. Subsequently, the remaining cells in the plate were digested again and cultured. This step was repeated between three and five times.

Proliferation kinetics. Cells from passage 5 were used to analyze proliferation kinetics. MB-ECs and E-ECs were seeded in 24-well plates (cat. no. 3524; Corning Life Sciences) at a density of $1 \times 10^{4}$ cells/well. The cells from three random wells were counted each day for 7 days. Proliferation curves were plotted according to mean values. The population doubling time (PDT) was calculated as follows: $\mathrm{PDT}=\left(\mathrm{t}-\mathrm{t}_{0}\right)$ $\lg 2 /\left(\lg \mathrm{N}_{\mathrm{t}}-\lg \mathrm{N}_{0}\right)$, where $\mathrm{t}_{0}$ is the start time of the logarithmic proliferation period, $t$ is the termination time of the logarithmic proliferation period, $\mathrm{N}_{0}$ is the initial number of cells in the logarithmic proliferation period and $\mathrm{N}_{\mathrm{t}}$ the final number of cells in the logarithmic proliferation period.

In vitro scratch assay. MB-ECs and E-ECs were seeded and grown to confluence in a 6-well plate (cat. no. 3516; Corning Life Sciences). Both cell types were starved for $12 \mathrm{~h}$ in DMEM/F12. The scratch was performed with a pipette tip running through the dish. The plates were washed twice with fresh medium to remove non-adherent cells, and the cells were subsequently cultured in DMEM/F12 at $37^{\circ} \mathrm{C}$ for $48 \mathrm{~h}$. Cell migration was evaluated by measuring the wound area under a light microscope.

Epithelial-mesenchymal transdifferentiation (EMT) assay in vitro. MB-ECs and E-ECs were seeded and grown to confluence in a six-well plate. All cells were cultured for $24 \mathrm{~h}$ in DMEM/F12 + 10\% FBS. The medium was changed to $\mathrm{DMEM} / \mathrm{F} 12+10 \% \mathrm{FBS}+3 \mathrm{ng} / \mathrm{ml} \mathrm{TGF}-\beta 1$ (dissolved in $\mathrm{ddH}_{2} \mathrm{O}$; cat. no. 96-100-21; PeproTech, Inc.). The cells were cultured at $37^{\circ} \mathrm{C}$ for 6,12 or $24 \mathrm{~h}$. As a control group, cells were cultured in DMEM/F12 + 10\% FBS.

$R N A$ extraction and reverse transcription-quantitative PCR assay ( $q P C R)$. Total cellular RNA was isolated using TRIzol ${ }^{\circledR}$ Reagent (cat. no. 15596026; Invitrogen; Thermo Fisher Scientific, Inc.) with genomic DNA removed. RNA quality was assessed by spectrophotometry. RNA (1- $\mu \mathrm{g}$ aliquots) was reverse-transcribed into complementary DNA (cDNA) using a RevertAid First Strand cDNA Synthesis kit (cat. no. K1621; Thermo Fisher Scientific, Inc.) according to the manufacturer's instructions. cDNA was amplified using a Taq PCR Master Mix kit (cat. no. KT201; Tiangen Biotech Co., Ltd.) in a PCR System (Applied Biosystems; Thermo Fisher Scientific, Inc.). The following thermocycling conditions were used for PCR (total volume per reaction, $10 \mu \mathrm{l}$ ): Initial denaturation at $95^{\circ} \mathrm{C}$ for $5 \mathrm{~min} ; 30$ cycles of $95^{\circ} \mathrm{C}$ for $30 \mathrm{sec}, 60^{\circ} \mathrm{C}$ for $30 \mathrm{sec}$ and $72^{\circ} \mathrm{C}$ for $30 \mathrm{sec}$; and final extension at $72^{\circ} \mathrm{C}$ for $10 \mathrm{~min}$. The reaction products were analyzed using $2.0 \%$ agarose gel electrophoresis and GelRed (cat. no. 41003; Biotium, Inc.). The sequence of each product was confirmed using DNA marker I ladder (cat. no. MD101; Tiangen Biotech Co., Ltd.).

qPCR was performed in duplicates using SYBR ${ }^{\circledR}$ Premix Ex Taq ${ }^{\mathrm{TM}}$ (cat. no. RR420A; Takara Biotechnology Co., Ltd.) and performed using a 7500 Real-Time PCR system (Applied Biosystems; Thermo Fisher Scientific, Inc.). qPCR reactions of $20 \mu \mathrm{l}$ for each sample consisted of cDNA (200 $\mu \mathrm{g}$ cDNA after dilution), 2X SYBR Premix Ex Taq, 50X ROX Reference Dye, $\mathrm{dH}_{2} \mathrm{O}$ and $10 \mu \mathrm{M}$ of each gene-specific primer. Primer sequences are shown in Table II. The following thermocycling conditions were used for qPCR: Initial denaturation at $95^{\circ} \mathrm{C}$ for $30 \mathrm{sec}$; 40 cycles of $95^{\circ} \mathrm{C}$ for $5 \mathrm{sec}, 60^{\circ} \mathrm{C}$ for $30 \mathrm{sec}$ and $72^{\circ} \mathrm{C}$ for $30 \mathrm{sec}$; and final extension at $72^{\circ} \mathrm{C}$ for 
Table I. Information of samples of human endometrium.

\begin{tabular}{|c|c|c|c|c|c|}
\hline $\begin{array}{l}\text { Patient } \\
\text { no. }\end{array}$ & $\begin{array}{l}\text { Age, } \\
\text { years }\end{array}$ & Disease & $\begin{array}{c}\text { Surgery or } \\
\text { operation check }\end{array}$ & Material method & $\begin{array}{l}\text { Sample } \\
\text { location }\end{array}$ \\
\hline 1 & 36 & Uterine fibroids & TCRM & Hysteroscope & Endometrium \\
\hline 2 & 32 & Endometrial polyps & TCRP & Hysteroscope & Endometrium \\
\hline 3 & 43 & $\begin{array}{l}\text { Abnormal uterine bleeding } \\
\text { associated with ovulatory } \\
\text { dysfunction }\end{array}$ & TCRE & Hysteroscope & Endometrium \\
\hline 4 & 42 & Ovarian cyst & Hysteroscopy & Hysteroscope & Endometrium \\
\hline 5 & 33 & $\begin{array}{l}\text { Ovarian serous } \\
\text { cystadenoma }\end{array}$ & Hysteroscopy & Hysteroscope & Endometrium \\
\hline 6 & 26 & Endometrial polyps & TCRP & Hysteroscope & Endometrium \\
\hline 7 & 39 & Ovarian cyst & Hysteroscopy & Hysteroscope & Endometrium \\
\hline 8 & 31 & Endometrial polyps & TCRP & Hysteroscope & Endometrium \\
\hline 9 & 38 & $\begin{array}{l}\text { Pelvic inflammatory } \\
\text { disease, hydrosalpinx }\end{array}$ & Hysteroscopy & Hysteroscope & Endometrium \\
\hline
\end{tabular}

TCRM, transcervical resection of submucous fibroids; TCRE, transcervical resection of the endometrium; TCRP, transcervical resection of polyps.

10 min. Relative mRNA abundance was calculated using the $2^{-\Delta \Delta \mathrm{Cq}}$ method (9) and normalized to the expression levels of GAPDH. The primer pairs used for qPCR are listed in Table II.

Flow cytometry. Following digestion into single cells with warmed $0.25 \%$ trypsin-EDTA, MB-ECs and E-ECs were incubated with anti-CD90-PE (1:200; cat. no. bs-10430R-PE; BIOSS), anti-CD34-PE (1:200; cat. no. bs-0646R-PE; BIOSS), unconjugated antibodies or matched-isotype control IgG (1:200; cat. no. bs-0295P-PE; BIOSS) for $1 \mathrm{~h}$ at room temperature and analyzed via flow cytometry using a BD Accuri $^{\text {TM }}$ C6 flow cytometer (BD Biosciences). Data were analyzed using CFlow Plus software (v1.0.264.15; Accuri Cytometers, Inc.). Events with forward scatter (FSC) $<12,500,000$ and side scatter (SSC) $<5,000,000$ were gated in P1, and the events in P1 with FSC $>2,000,000$ and SSC $>100,000$ were gated in P2 to remove large cell adhesion bodies and small cell debris.

Cellular immunofluorescence assay. Cultures of MB-ECs and E-ECs at passage 3 were seeded $\left(0.5 \times 10^{5}\right.$ cells $/ 1-\mathrm{cm}^{2}$ glass coverslip) on glass coverslips coated with poly-L-lysine. For immunofluorescent assay analysis, the MB-ECs and E-ECs were fixed with $4 \%$ paraformaldehyde for $15 \mathrm{~min}$ at room temperature and washed three times ( $5 \mathrm{~min} /$ wash) with PBS. For vimentin (Vim) staining, cells were permeabilized with $0.25 \%$ Triton X-100 (cat. no. X100; Sigma-Aldrich; Merck KGaA) for $10 \mathrm{~min}$. Cells were washed three times (5 min/wash) with PBS, then blocked with $10 \%$ goat serum (cat. no. ZLI-9021; OriGene Technologies, Inc.) for $1 \mathrm{~h}$ at room temperature prior to incubation with primary antibodies. The cells were incubated with the following primary antibodies: Anti-Vim (1:250; cat. no. ab92547; Abcam) and anti-cytokeratin 18 (CK18; 1:250; cat. no. ab133263; Abcam) at $4^{\circ} \mathrm{C}$ overnight. Cells were washed three times $(5 \mathrm{~min}$ per wash) with PBS, followed by incubation with Alexa Fluor ${ }^{\circledR}$ 594-conjugated goat anti-rabbit secondary antibody (1:100; cat. no. ZF-0516; OriGene Technologies, Inc.) in the dark for $1 \mathrm{~h}$ at room temperature. Finally, $10 \mu \mathrm{g} / \mathrm{ml}$ of DAPI (cat. no. D9542; Sigma-Aldrich; Merck KGaA) were used to label cell nuclei for $15 \mathrm{~min}$, and images were captured using a fluorescence microscope (TE-2000-E; Nikon Corporation). PBS was used as a substitute for primary antibodies as a technical control.

Western blotting. Cells were prepared and lysed in ice-cold RIPA buffer (cat. no. 89900; Thermo Fisher Scientific, Inc.) containing freshly added Halt Phosphatase Inhibitor Cocktail and Protease Inhibitor Cocktail, and protein concentrations were determined using the Bradford protein assay (Bio-Rad Laboratories, Inc.). Samples of $20 \mu \mathrm{g}$ proteins were separated via SDS-PAGE on a $12 \%$ gel (Bio-Rad Laboratories, Inc.) and proteins were immunoblotted onto nitrocellulose membranes. The membranes were blocked in 5\% non-fat milk for $1 \mathrm{~h}$ at room temperature and probed with primary antibodies [anti- $\beta$-actin (1:1,000; cat. no. 60008-1-Ig; ProteinTech Group, Inc.), anti-Vim (1:1,000; cat. no. ab92547; Abcam) or anti-CK18 (1:1,000; cat. no. ab133263; Abcam) $]$ at $4^{\circ} \mathrm{C}$ overnight, followed by HRP-conjugated secondary antibodies [HRP-conjugated Affinipure Goat Anti-Mouse IgG (H + L) (cat. no. SA00001-1; 1:2,500; ProteinTech Group, Inc.) and HRP-conjugated Affinipure Goat Anti-Rabbit IgG (H + L) (cat. no. SA00001-2; 1:2,500; ProteinTech Group, Inc.)] for $2 \mathrm{~h}$ at room temperature. The blots were visualized using Immobilon Western Chemiluminescent HRP Substrate (cat. no. WBKLS0500; MilliporeSigma), and images were captured using the ECL Tanon 5500 system (Tanon Science and Technology Co., Ltd.). Protein expression was normalized to the expression levels of $\beta$-actin. 
Table II. Primer sequences used for reverse transcription-quantitative PCR.

\begin{tabular}{llcc}
\hline Gene & \multicolumn{1}{c}{ Primer sequence } & Melting temperature, ${ }^{\circ} \mathrm{C}$ & Product length, bp \\
\hline \multirow{2}{*}{ Vim } & F: 5'-GGACCAGCTAACCAACGACA-3' & 60.0 & 116 \\
\multirow{2}{*}{ CK18 } & R: 5'-CGGCTTCCTCTCTCTGAAGC-3' & 60.2 & 115 \\
\multirow{2}{*}{ GAPDH } & F: 5'-CCTACAAGCCCAGATTGCCA-3' & 60.0 & 104 \\
& R: 5'-CCGAGCCAGCTCGTCATATT-3' & 60.0 & \\
& F: 5'-TATGACAACAGCCTCAAGAT-3' & 54.1 & 54.4 \\
\hline
\end{tabular}

Vim, vimentin; CK18, cytokeratin 18; F, forward; R, reverse.
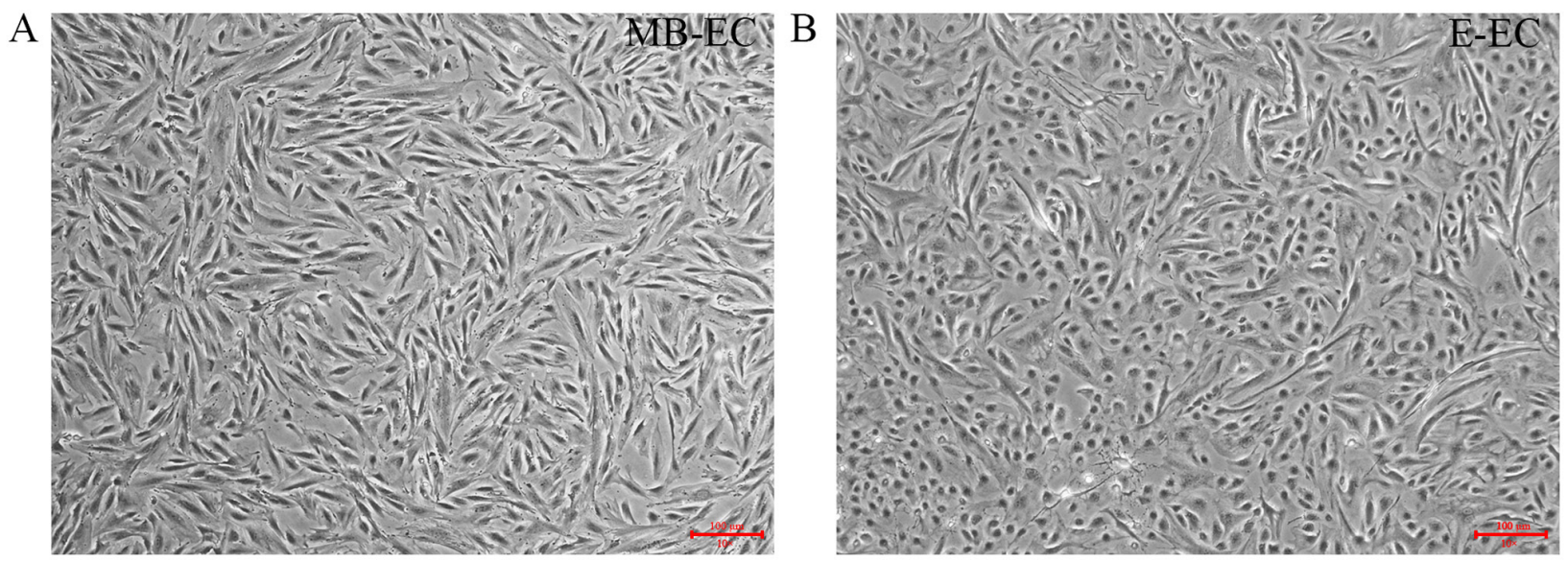

Figure 1. Morphology of cultured cells in vitro. Morphology of (A) MB-ECs and (B) E-ECs at passage 3 . Scale bar=100 $\mu \mathrm{m}$. ECs, endometrial cells; MB, menstrual blood-derived; E, endometrium-derived.

Statistical analysis. Data are presented as the mean \pm SEM for $n=3$ samples. Statistical differences between two groups were analyzed using Student's t-test (two-tailed unpaired). Comparisons between multiple groups were performed using one-way ANOVA followed by Tukey's post hoc test. $\mathrm{P}<0.05$ was considered to indicate a statistically significant difference.

\section{Results}

Isolation, culture and morphology of MB-ECs and E-ECs. MB-ECs were isolated from MB by density gradient centrifugation. MB-ECs demonstrated a flat two-dimensional morphology after three generations of subculture (Fig. 1A). E-ECs were isolated from endometrial tissue by enzymatic digestion. E-ECs demonstrated a round and flattened shape morphology after three generations of subculture (Fig. 1B), distinct from the MB-EC cell morphology of small spindle-like cells (Fig. 1A).

Characterization of MB-ECs and E-ECs. In order to confirm that the isolated and cultured cells were not mesenchymal stem cells or hematopoietic stem cells, the cell expression of CK18 (a marker of epithelial cells), Vim (a marker of mesenchymal stem cells), CD90 (a marker of mesenchymal stem cells) and CD34 (a marker for hematopoietic stem cells) was quantified $(10,11)$. Specific markers of MB-ECs and E-ECs were detected via immunofluorescence and flow cytometry. Immunofluorescence assays indicated that MB-ECs and E-ECs both expressed CK18 (Fig. 2A), but neither expressed Vim (Fig. 2B). Flow cytometry assays demonstrated that neither MB-ECs nor E-ECs expressed CD90 and CD34 (Fig. 2C).

Cell proliferation and migration capacity assays. The proliferation curves of both MB-ECs and E-ECs appeared as typically sigmoidal, which consisted of a latent phase, a logarithmic phase and a plateau phase (Fig. 3). The PDT of MB-ECs was $22.05 \pm 0.44 \mathrm{~h}$ and that of E-ECs was $20.85 \pm 0.82 \mathrm{~h}$ (Fig. 3; $\mathrm{P}<0.05)$. The migration capacity assay results indicated that the wounds in confluent MB-ECs and E-ECs healed after $48 \mathrm{~h}$, but the wound area of MB-ECs was significantly smaller than that of E-ECs at $48 \mathrm{~h}(\mathrm{P}<0.01$; Fig. 4).

TGF- $\beta 1$ effect on EMT gene expression. Following TGF- $\beta 1$ treatment, CK18 mRNA expression in MB-ECs and E-ECs decreased, and Vim mRNA expression in MB-ECs and E-ECs increased. The CK18 mRNA expression level in MB-ECs decreased significantly after $6 \mathrm{~h}(\mathrm{P}<0.01 \mathrm{vs} .0 \mathrm{~h})$ and in E-ECs after $12 \mathrm{~h}(\mathrm{P}<0.01$ vs. 0 h; Fig. 5A). The CK18 mRNA expression level gradually increased but remained significantly lower than its initial level after $24 \mathrm{~h}$ ( $\mathrm{P}<0.01$ vs. $0 \mathrm{~h}$; Fig. 5A and B). Vim mRNA expression level in MB-ECs and E-ECs significantly increased after $6 \mathrm{~h}(\mathrm{P}<0.05$ vs. 0 h; Fig. $5 \mathrm{~A}$ and $\mathrm{C})$, but was significantly lower 


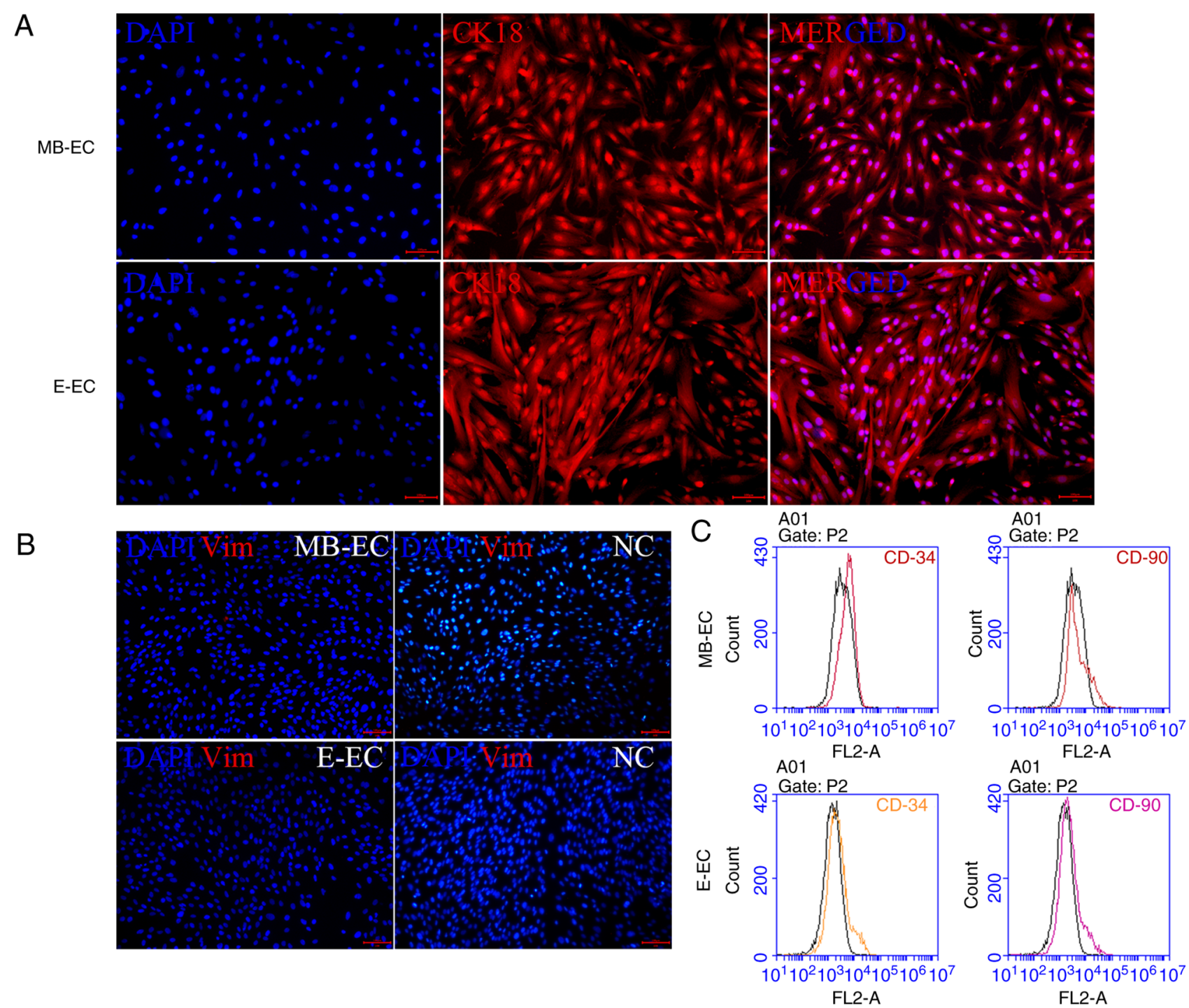

Figure 2. Detection of cell markers by immunofluorescence staining and flow cytometry. (A) MB-ECs and E-ECs expressed CK18. (B) MB-ECs and E-ECs did not express Vim. (C) MB-ECs and E-ECs did not express CD34 and CD90. Scale bar=100 $\mu$ m. CK18, cytokeratin 18; Vim, vimentin; NC, negative control; ECs, endometrial cells; MB, menstrual blood-derived; E, endometrium-derived.

than its initial level after $24 \mathrm{~h}(\mathrm{MB}-\mathrm{EC}, \mathrm{P}<0.05$ vs. $0 \mathrm{~h}$; E-ECs, $\mathrm{P}<0.001$ vs. 0 h; Fig. 5A and C).

TGF- $\beta 1$ effect on EMT protein expression. Following TGF- $\beta 1$ treatment, CK18 protein expression in E-ECs significantly decreased at $24 \mathrm{~h}(\mathrm{P}<0.01$ vs. $0 \mathrm{~h})$, but significantly increased in MB-ECs at $12 \mathrm{~h}(\mathrm{P}<0.001$ vs. $0 \mathrm{~h})$ and $24 \mathrm{~h}(\mathrm{P}<0.01$ vs. $0 \mathrm{~h}$; Fig. 6A and B). Vim protein expression in MB-ECs was significantly upregulated at $6 \mathrm{~h}(\mathrm{P}<0.01 \mathrm{vs.} 0 \mathrm{~h})$, reached its highest level at $12 \mathrm{~h}(\mathrm{P}<0.001 \mathrm{vs} .0 \mathrm{~h})$, and then decreased slightly at $24 \mathrm{~h}$, while significantly higher than that at $0 \mathrm{~h}(\mathrm{P}<0.001 \mathrm{vs}$. $0 \mathrm{~h}$; Fig. 6A and C). Vim protein expression in E-ECs was significantly upregulated at 6 and $12 \mathrm{~h}(\mathrm{P}<0.05$ vs. $0 \mathrm{~h})$, then decreased to initial levels at $24 \mathrm{~h}$ (Fig. 6A and C).

\section{Discussion}

Endometrial epithelial cells are a functional layer of the uterine surface and play an important role in the implantation of fertilized eggs (12). Wounding or bacterial infection may result in severe uterine diseases and even infertility (8). Therefore, studying endometrial epithelial cell biological function is of great relevance and provides a scientific basis for the potential treatment of endometrial epithelial defects (13). MB-ECs and E-ECs are two types of endometrial cells at different developmental stages. MB, the top two-thirds of the functional layer of the E, is shed during menstruation, and contains cells (a large number of epithelial and stromal cells) and tissues from the functional layer of the $\mathrm{E}(14,15)$. This course of events is the process of E-ECs forming MB-ECs. Therefore, it was hypothesized that MB-ECs and E-ECs had different morphological and biological characteristics. As it requires surgery to be sampled, endometrial tissue is difficult to obtain from healthy women. Although endometrial tissues were obtained from patients undergoing hysterectomy and MB from healthy women, the biological characteristics of the two cell types were comparable. Isolated MB-ECs and E-ECs expressed CK18 and not Vim, CD34 (a surface marker of hematopoietic stem cells) (10) nor CD90 (a surface marker of mesenchymal cells) (11). The two cell types demonstrated different cell morphology, proliferation and migration ability. 


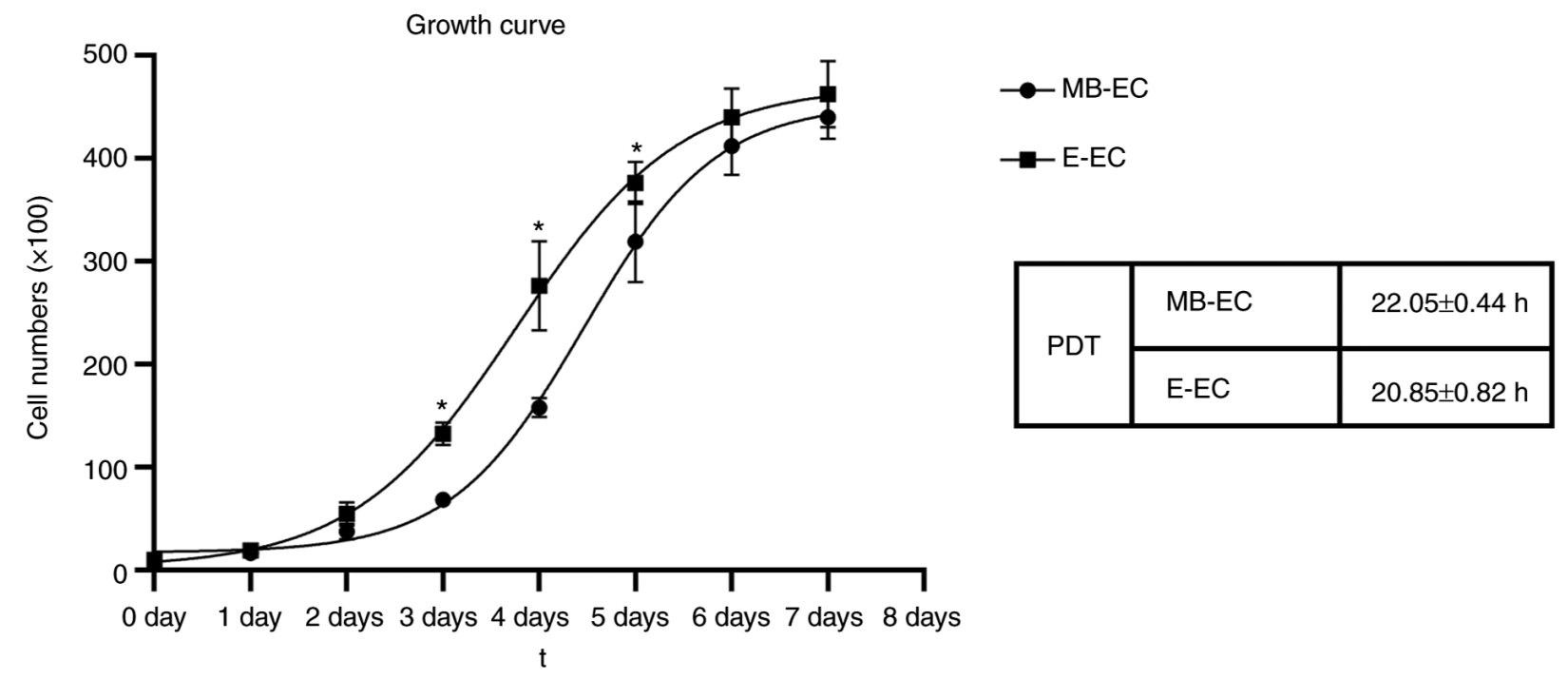

Figure 3. Proliferation curves and PDT of MB-ECs and E-ECs. "P<0.05 vs. E-ECs. PDT, population doubling time; ECs, endometrial cells; MB, menstrual blood-derived; E, endometrium-derived.

A

$\mathrm{Oh}$

$16 \mathrm{~h}$

$24 \mathrm{~h}$

$48 \mathrm{~h}$
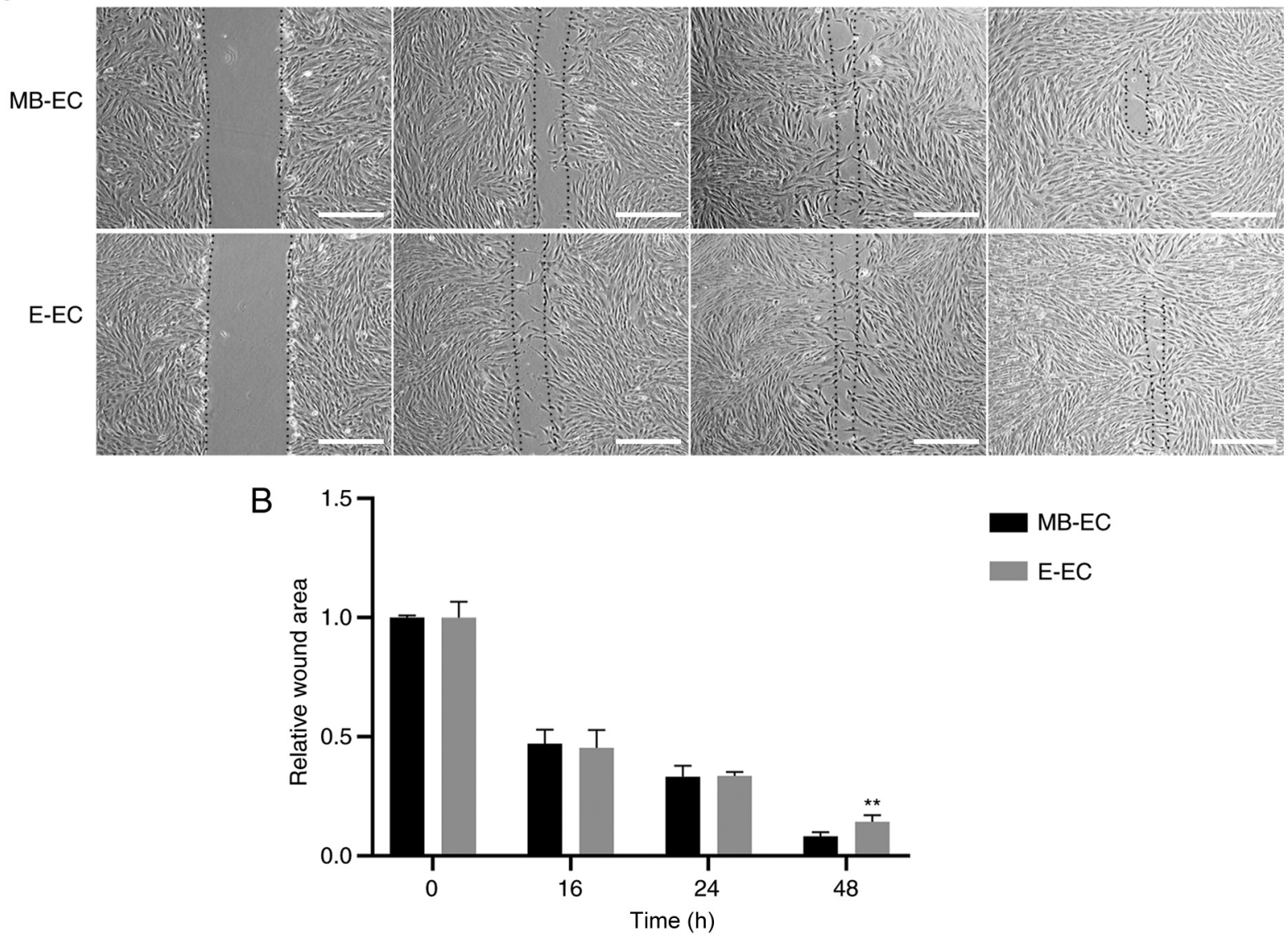

Figure 4. Migration capacity of MB-ECs and E-ECs. (A) Wound healing migration assay for MB-ECs (top) and E-ECs (bottom) at 0, 16, 24 and $48 \mathrm{~h}$. (B) Relative wound area of MB-ECs and E-ECs. Scale bar=500 $\mu \mathrm{m}$. ${ }^{* *} \mathrm{P}<0.01$ vs. E-ECs. ECs, endometrial cells; MB, menstrual blood-derived; E, endometrium-derived.

MB-ECs exhibited a small, flat, spindle-like cell morphology (15), and E-ECs appeared rounder and flattened cells.

Cell proliferation is closely related to the cell development stage. A previous study indicated that the development of the terminal end of the cells and cell cycle exit substantially reduced their proliferation ability (8). MB-ECs were derived from the development of the terminal end of E-ECs, and the PDT of MB-ECs was greater than that of E-ECs. Cell migration happens throughout life and is a coordinated physiological process used by normal cells during embryonic morphogenesis, wound 
A

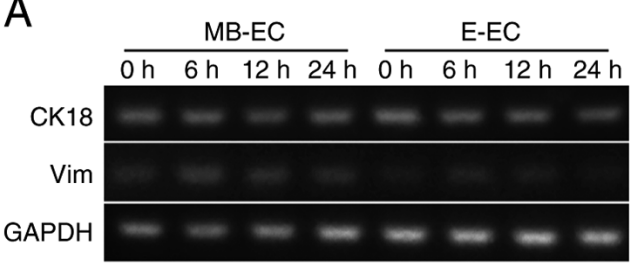

B

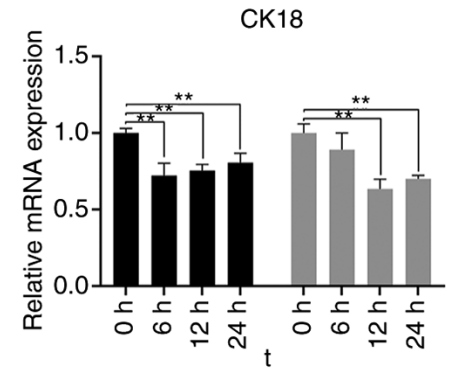

$\mathrm{C}$

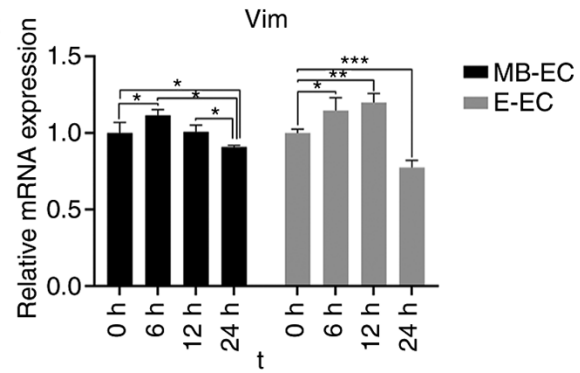

Figure 5. Effect of TGF- $\beta 1$ on cell epithelial-mesenchymal transdifferentiation. (A) mRNA expression of CK18, Vim and GAPDH detected by PCR. (B) Relative CK18 mRNA expression detected by RT-qPCR. (C) Relative Vim mRNA expression detected by RT-qPCR. ${ }^{*} \mathrm{P}<0.05,{ }^{* * *} \mathrm{P}<0.01,{ }^{* * * *} \mathrm{P}<0.001$. Vim, vimentin; CK18, cytokeratin 18; ECs, endometrial cells; MB, menstrual blood-derived; E, endometrium-derived; RT-qPCR, reverse transcription-quantitative PCR.

A

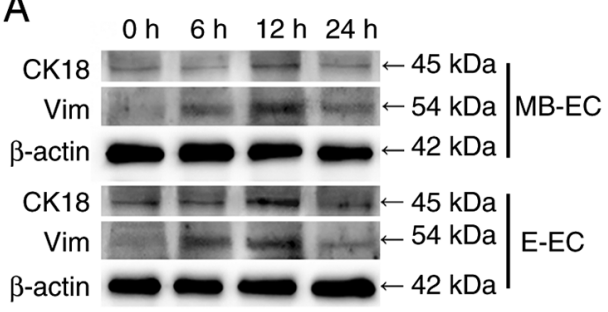

$\mathrm{B}$

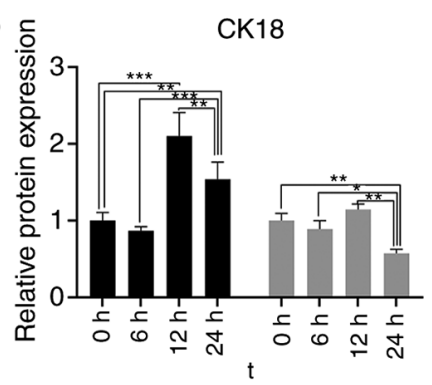

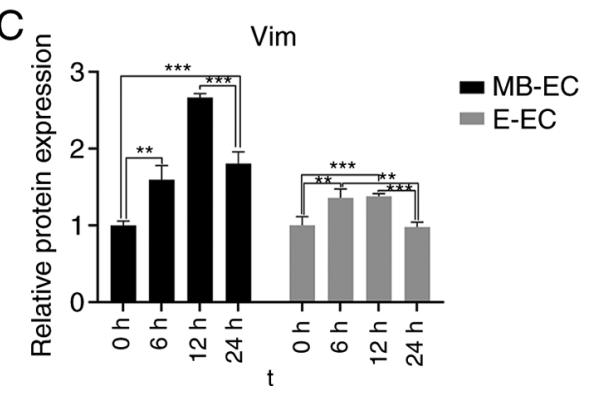

Figure 6. Effect of TGF- $\beta 1$ on cell epithelial-mesenchymal transdifferentiation. (A) Protein expression of CK18, Vim and $\beta$-actin detected by western blot. (B) Relative CK18 protein expression. (C) Relative Vim protein expression. ${ }^{*} \mathrm{P}<0.05,{ }^{* *} \mathrm{P}<0.01,{ }^{* * *} \mathrm{P}<0.001$. Vim, vimentin; CK18, cytokeratin 18 ; ECs, endometrial cells; MB, menstrual blood-derived; E, endometrium-derived.

healing and cell transport, while tumor cells spread within tissues (16-18). The in vitro scratch assay is a simple, economical and well-developed method that mimics the migration of cells in vivo to study cell migration in vitro (19). The present study demonstrated that MB-ECs had a higher migration ability than E-ECs. Cell movement is a complex process involving a number of steps, including the disruption of cell-cell junctions, cytoskeletal rearrangements and constant remodeling of adhesive contacts with the extracellular matrix (18). A previous study indicated that, at the end of the menstrual cycle, with withdrawal of steroid hormone support, the activity of matrix-degrading enzymes induced endometrial destruction (20), which may lead to enhanced cell migration. Implantation of the human embryo into the uterine wall during the early stages involves embryo apposition and adhesion to the endometrial epithelium, followed by penetration through the epithelium and invasion of the embryonic trophoblast through the endometrial stroma (21). Estradiol administration has been previously demonstrated to have a marked effect on migration kinetics, induced non-dividing gland cells to enter the cell cycle and decreased the loss of epithelial cells (22). Decreased cell death in the mouse uterine epithelium has been observed after repeated estrogen administration (23). However, in intact rabbits with induced ovulation, the uterine epithelium is desensitized to estrogens (22). MB-ECs and E-ECs are two cell types at different developmental stages; MB-ECs are derived from the development of the terminal end of E-ECs (24). In the present study, MB-ECs were isolated from menstrual blood, and E-ECs were isolated from endometrial tissue. The cell proliferation curve and migration ability in MB-ECs and E-ECs were found to be different.
EMT is an organized process in which epithelial cells are induced to differentiate into a mesenchymal phenotype, and has been previously recognized in developmental biology as a means to achieve morphogenetic change (25). The maternal endometrial epithelium undergoes EMT-related changes during the embryo implantation period (26). Molecular signals from within the maternal E regulate the EMT process; a number of these signals have been implicated in embryo implantation failure (26). Human endometrial stromal cells can maintain endometrial homeostasis and play a critical role in repairing endometrial injury, and mesenchymal cells can increase the proliferation of damaged endometrial stromal cells (27). A previous study indicated that TGF- $\beta 1 \mathrm{mRNA}$ and protein expression increased around menstruation to contribute to tissue repair following endometrial shedding (28). TGF- $\beta 1$ is secreted abundantly in the E, specifically in patients with endometriosis $(29,30)$. TGF- $\beta 1$ not only induces apoptosis but also simultaneously induces EMT (31), and endometrial epithelial cells can induce EMT through TGF- $\beta 1$ (32). The acquisition of mesenchymal markers (such as N-cadherin and Vim) and the loss of epithelial markers (such as E-cadherin) are hallmarks of EMT in endometriosis (33) and adenomyosis (34). In addition, TGF- $\beta 1$-induced EMT was previously demonstrated to lead to the migration and invasion of local epithelial cells (31). The present results indicated that MB-ECs and E-ECs may induce EMT through TGF- $\beta 1$; CK18 gene expression was downregulated and Vim expression upregulated. A previous study indicated that TGF- $\beta 1$ treatment induced EMT in a dose- and time-dependent manner (31). CK18 and Vim expression returned to their initial levels after $24 \mathrm{~h}$, which may indicate that TGF- $\beta 1$ was absorbed and removed by the cells. 
In conclusion, the present study isolated human MB-ECs and E-ECs, which demonstrated differences in morphology and cell biology; however, both cell types could exhibit EMT via TGF- $\beta 1$ induction in vitro. Therefore, MB-ECs could be used in place of E-ECs for cell biology research and potential bioengineering applications. MB-ECs were isolated from menstrual blood, a convenient source with no harm to the human body. E-ECs were isolated from endometrial tissue, which is an inconvenient source that damages women's uterine tissue. Although some differences were noticed between the two sources of endometrial cells (such as PDT and migration ability), their functions were found to be similar.

\section{Acknowledgements}

Not applicable.

\section{Funding}

The present study was supported by the Natural Science Foundation of The Xinjiang Uygur Autonomous Region funded projects (grant no. 2016D01C280).

\section{Availability of data and materials}

The datasets used and/or analyzed during the current study are available from the corresponding author on reasonable request.

\section{Authors' contributions}

$\mathrm{LZ}$ and YD conceived and designed the experiments of the current study. MJ and ZC performed the experiments. LZ and MJ wrote the manuscript. MJ and LY analyzed the data. LZ and MJ confirm the authenticity of all the raw data. All authors have read and approved the final manuscript.

\section{Ethics approval and consent to participate}

All samples were collected under a protocol approved by the institutional review board of the Gynecology Center of The First Affiliated Hospital of Xinjiang Medical University (China), and written informed consent was obtained from each donor.

\section{Patient consent for publication}

Not applicable.

\section{Competing interests}

The authors declare that they have no competing interests.

\section{References}

1. Jabbour HN, Kelly RW, Fraser HM and Critchley HO: Endocrine regulation of menstruation. Endocr Rev 27: 17-46, 2006.

2. Gargett CE, Schwab KE, Zillwood RM, Nguyen HP and Wu D Isolation and culture of epithelial progenitors and mesenchymal stem cells from human endometrium. Biol Reprod 80: 1136-1145, 2009.
3. Chan RW, Schwab KE and Gargett CE: Clonogenicity of human endometrial epithelial and stromal cells. Biol Reprod 70: 1738-1750, 2004.

4. Smalley MJ and Clarke RB: The mammary gland 'side population': A putative stem/progenitor cell marker? J Mammary Gland Biol Neoplasia 10: 37-47, 2005.

5. Hennes A, Held K, Boretto M, De Clercq K, Van den Eynde C, Vanhie A, Van Ranst N, Benoit M, Luyten C, Peeraer K, et al: Functional expression of the mechanosensitive PIEZO1 channel in primary endometrial epithelial cells and endometrial organoids. Sci Rep 9: 1779, 2019.

6. Meng X, Ichim TE, Zhong J, Rogers A, Yin Z, Jackson J, Wang H, Ge W, Bogin V, Chan KW, et al: Endometrial regenerative cells: A novel stem cell population. J Transl Med 5: 57, 2007.

7. Chen L, Qu J, Cheng T, Chen X and Xiang C: Menstrual blood-derived stem cells: Toward therapeutic mechanisms, novel strategies, and future perspectives in the treatment of diseases. Stem Cell Res Ther 10: 406, 2019.

8. Hu J, Song K, Zhang J, Zhang Y and Tan BZ: Effects of menstrual blood-derived stem cells on endometrial injury repair. Mol Med Rep 19: 813-820, 2018.

9. Livak KJ and Schmittgen TD: Analysis of relative gene expression data using real-time quantitative PCR and the 2(-Delta Delta C(T)) method. Methods 25: 402-408, 2001.

10. Krause DS, Ito T, Fackler MJ, Smith OM, Collector MI, Sharkis SJ and May WS: Characterization of murine CD34, a marker for hematopoietic progenitor and stem cells. Blood 84: 691-701, 1994.

11. L Ramos T, Sánchez-Abarca LI, Muntión S, Preciado S, Puig N, López-Ruano G, Hernández-Hernández Á, Redondo A, Ortega R, Rodríguez C, et al: MSC surface markers (CD44, CD73, and CD90) can identify human MSC-derived extracellular vesicles by conventional flow cytometry. Cell Commun Signal 14: 2, 2016.

12. Salamonsen LA, Evans J, Nguyen H and Edgell TA: The microenvironment of human implantation: Determinant of reproductive success. Am J Reprod Immunol 75: 218-225, 2016.

13. Liang L, Wang L, Zhou S, Li J, Meng L, Zhang H, Cui C and Zhang C: Exosomes derived from human umbilical cord mesenchymal stem cells repair injured endometrial epithelial cells. J Assist Reprod Genet 37: 395-403, 2020.

14. Padykula HA: Regeneration in the primate uterus. In: Biology of the Uterus. Springer, pp279-288, 1989.

15. Toyoda M, Cui Ch and Umezawa A: Myogenic transdifferentiation of menstrual blood-derived cells. Acta Myol 26: 176-178, 2007.

16. Ridley AJ, Schwartz MA, Burridge K, Firtel RA, Ginsberg MH, Borisy G, Parsons JT and Horwitz AR: Cell migration: Integrating signals from front to back. Science 302: 1704-1709, 2003.

17. Oh JM, Venters CC, Di C, Pinto AM, Wan L, Younis I, Cai Z, Arai C, So BR, Duan J and Dreyfuss G: U1 snRNP regulates cancer cell migration and invasion in vitro. Nat Commun 11: 1, 2020.

18. Gentilini D, Busacca M, Di Francesco S, Vignali M, Viganò $P$ and Di Blasio AM: PI3K/Akt and ERK1/2 signalling pathways are involved in endometrial cell migration induced by 17 beta-estradiol and growth factors. Mol Hum Reprod 13: 317-322, 2007.

19. Liang CC, Park AY and Guan JL: In vitro scratch assay: A convenient and inexpensive method for analysis of cell migration in vitro. Nat Protoc 2: 329-333, 2007.

20. Salamonsen LA: Tissue injury and repair in the female human reproductive tract. Reproduction 125: 301-311, 2003.

21. Grewal S, Carver JG, Ridley AJ and Mardon HJ: Implantation of the human embryo requires Rac1-dependent endometrial stromal cell migration. Proc Natl Acad Sci USA 105: 16189-16194, 2008.

22. Conti CJ, Gimenez-Conti IB, Conner EA, Lehman JM and Gerschenson LE: Estrogen and progesterone regulation of proliferation, migration, and loss in different target cells of rabbit uterine epithelium. Endocrinology 114: 345-351, 1984.

23. Martin L, Pollard JW and Fagg B: Oestriol, oestradiol-17beta and the proliferation and death of uterine cells. J Endocrinol 69: 103-115, 1976.

24. Kato K, Yoshimoto M, Kato K, Adachi S, Yamayoshi A, Arima T, Asanoma K, Kyo S, Nakahata T and Wake N: Characterization of side-population cells in human normal endometrium. Hum Reprod 22: 1214-1223, 2007.

25. Kokkinos MI, Murthi P, Wafai R, Thompson EW and Newgreen DF: Cadherins in the human placenta-epithelial-mesenchymal transition (EMT) and placental development. Placenta 31: 747-755, 2010.

26. Owusu-Akyaw A, Krishnamoorthy K, Goldsmith LT and Morelli SS: The role of mesenchymal-epithelial transition in endometrial function. Hum Reprod Update 25: 114-133, 2019. 
27. Wang J, Hu R, Xing Q, Feng X, Jiang X, Xu Y and Wei Z: Exosomes derived from umbilical cord mesenchymal stem cells alleviate mifepristone-induced human endometrial stromal cell injury. Stem Cells Int 2020: 6091269, 2020.

28. Omwandho CO, Konrad L, Halis G, Oehmke F and Tinneberg HR: Role of TGF-betas in normal human endometrium and endometriosis. Hum Reprod 25: 101-109, 2010.

29. Young VJ, Brown JK, Saunders PT, Duncan WC and Horne AW: The peritoneum is both a source and target of TGF- $\beta$ in women with endometriosis. PLoS One 9: e106773, 2014.

30. Ibrahim MG, Elghonaimy EA, Schäfer S, Vennemann M, Kliesch S, Kiesel L, Götte M and Schüring AN: Seminal plasma (SP) induces a rapid transforming growth factor beta 1 (TGF 31 )-independent up-regulation of epithelial-mesenchymal transdifferentiation (EMT) and myofibroblastic metaplasia-markers in endometriotic (EM) and endometrial cells. Arch Gynecol Obstet 299: 173-183, 2019.

31. Song J: EMT or apoptosis: A decision for TGF-beta. Cell Res 17: 289-290, 2007
32. Yao Y, Chen R, Wang G, Zhang Y and Liu F: Exosomes derived from mesenchymal stem cells reverse EMT via TGF- $\beta 1 / \mathrm{Smad}$ pathway and promote repair of damaged endometrium. Stem Cell Res Ther 10: 225, 2019.

33. Bartley J, Jülicher A, Hotz B, Mechsner S and Hotz H: Epithelial to mesenchymal transition (EMT) seems to be regulated differently in endometriosis and the endometrium. Arch Gynecol Obstet 289: 871-881, 2014.

34. Chen YJ, Li HY, Huang CH, Twu NF, Yen MS, Wang PH, Chou TY, Liu YN, Chao KC and Yang MH: Oestrogen-induced epithelial-mesenchymal transition of endometrial epithelial cells contributes to the development of adenomyosis. J Pathol 222: 261-270, 2010.

(i) (5) This work is licensed under a Creative Commons Attribution-NonCommercial-NoDerivatives 4.0 International (CC BY-NC-ND 4.0) License. 